\title{
Distribution Pattern of Enteropathogens in Greater Imphal Area of Imphal River, Manipur
}

\author{
TH. ALEXANDER SINGH ${ }^{1}$, L. BIJEN MEITEI ${ }^{2}$ and N. SANAMACHA MEETEI ${ }^{3}$ \\ ${ }^{1}$ Research Scholar, CMJ University, Laitumkhrah Shillong, Meghalaya - 793 003, India. \\ 2Junior Research Officer, Directorate of Environment, Porompat, Imphal East - 795 005, Manipur. \\ ${ }^{3}$ Directorate of Environment, Imphal East - 795 010, Manipur, India.
}

(Received: July 12, 2012; Accepted: September 17, 2012)

\begin{abstract}
An investigation on enteropathogens in the water of Imphal river at five different sites within greater Imphal area of Manipur was carried out as a part of water quality documentation at monthly intervals for one year. Densities of enteropathogens were found to be high during rainy season and low during summer and winter seasons. The degrees of survival for the different bacteria were influenced by various environmental factors as well as anthropogenic activities.
\end{abstract}

Key words: Enteropathogens, anthropogenic, allochthonous, indicator organism, pollution.

\section{INTRODUCTION}

The increasing anthropogenic activities in and around the aquatic ecosystems and their catchments areas in recent years, have contributed to large scale mineral enrichment and incidence of many pathogenic micro-organisms in different water bodies. Besides, many major water bodies are being degraded due to continuous heavy discharge of untreated waste and surface run-off, causing deleterious effects in flora and fauna and other aquatic organisms (Sah et al., 2000). The distribution pattern and periodicity of different organisms in water solely depends upon the imprint of preceeding environmental factors (Badge and Verma, 1982). As such the significance of those factors as potent ecological parameters can be appreciated by considering the structure, physico-chemical characteristics, flora and fauna, primary and secondary productivities of the water bodies.

Out of the many bacteria found in water, some are indicator of pollution and a small number of them are pathogenic. The coliform groups of bacteria are of great importance and include a number of organisms (Mc Kinney, 1962), causing different water borne diseases. Coliform bacterial contamination in urban and rural surface water has been a major public health concern for decades (Burton et al, 1987). The sources for the contamination of different water bodies (Weibel et al, 1964, Crane et al., 1983, Tunnicliff and Brinkler, 1984) and relationship between land use and coliform level (Faust, 1982) had already been established.

Water qualities especially those of rivers have been deteriorating due to disposal of garbage, religious offerings, sewage, recreational and constructional activities in the catchments areas. While many pollution problems affecting water quality are the direct result of human activity, some are less easily isolated (Cooper and Night, 1989). Contaminated water provides shelter to a variety of diverse micro-organisms (Khulbe et al., 1989), which many cause various water borne diseases.

Therefore, the present investigation has been carried out with the objectives to assess the degree of persistence and distribution patterns of enteropathogenic groups of bacteria in greater Imphal area of Imphal river. 


\section{MATERIAL AND METHODS}

Samples for the enumeration of bacteria were collected at monthly intervals from five (5) experimental sites within greater Imphal area of Imphal City, Manipur (1-Koirengei, 2-Lamlong, 3Sanjenthong,4-Ningom Thongjao, and 5-Lilong) during July, 2011 to June, 2012. Water samples from different sites were collected by means of shallow water sampler in a wide-mouthed bottle which is pre-sterilized. Samples were chilled and returned to the laboratory on the same day for analysis. Total coliform and fecal coliform were quantitatively estimated by using standard membrane filter technique with appropriate dilutions (APHA, 1989). Triplicate analysis was done for each parameter. Further qualitative characterization and verification, selective medium for subsequent biochemical test were carried out (Buchanan and Gibbons, 1984; APHA, 1989). For the calculation of ANOVAR (Analysis of variance) in different seasons, the methods of parker (1973) and Trivedi, Goel and Trisal (1987) were used in computing the analysis.

\section{RESULT AND DISCUSSIONS}

Coliform bacterial density at the dilution level of $10^{1}$ in the course of the river was found to be gradually increased from January onwards exhibiting peak value of $820.00 \mathrm{CFU} 100^{-1} \mathrm{ml}$ during rainy season of October and lowest value of 240.00 CFU $100^{-1} \mathrm{ml}$ during winter season of January (Table-1). Similar observations was reflected in the findings of Sharma and Bharadwaj (2000) and Sharma and Rajput (1996) that coliform bacterial density was found to be correlated with rainfall due to fecal runoff from the disturbed as well as undisturbed catchment areas. Similar observations were also reported by Geldreich (1976), Das and Pande (1986), Baxter-potter and Gilliand (1988), Cooper and Knight (1989) and Rajender and Khulbe (1998).

This trend of fluctuating density of total coliform population depend upon many factors such as physical chemical and environmental factors, including rainfall temperature, oxygen profile etc (Akpata, et al., 1993). The rainfall pattern influences the environmental condition of the water body

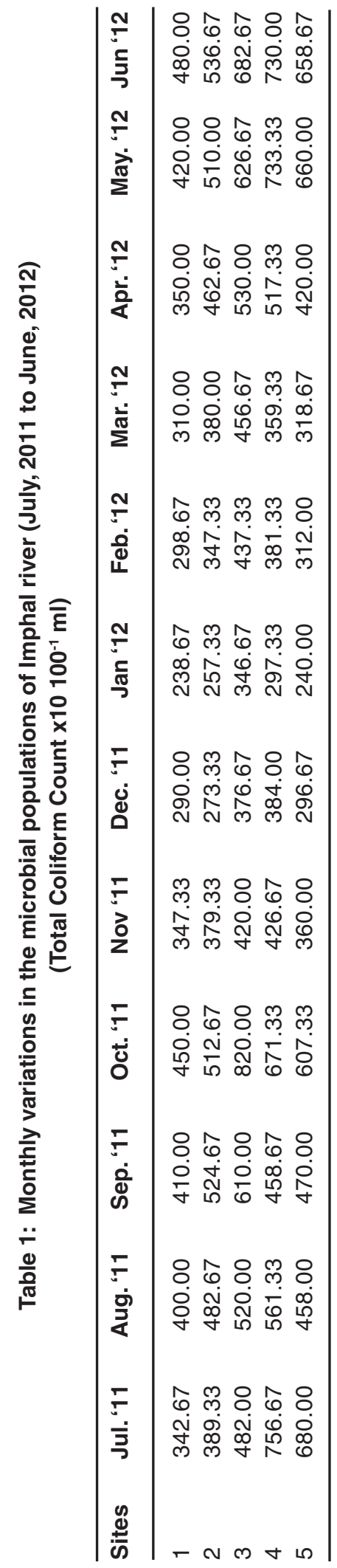


during which many biodegradable materials are washed and carried down, thus explaining increasing in high bacterial population (Hill and Webb, 1958). The survival of bacteria in water is directly correlated with the presence of some organic materials and there is fluctuation in the population with the increasing and decreasing loads of biodegradable waste input in the water system (Flint, 1989). On the other hand, Knox (1986) suggested those bacteria and algae as food sources for primary consumer such as zooplankton, benthic invertebrates and some fishes resulting in the decrease of bacterial density. Therefore, the results of the present findings were also closely related with the observations of Nwachukwu et al. (1989), Jama et al. (1986) and McSwain and Swank (1997).

The high count in fecal coliform population in the river might be resulted from fecal material of both human beings and animals. The same was reported by Sharma and Rajput (1996), Fatma et al. (1997), Shidhu and Khulbe (1998) and Khalil (2000) that they are mainly resulted from the continuous contamination of human and animal excreta. But, according to Faust et al. (1975), survival of fecal coliform was affected by many factors like interaction with metal, algal toxins, temperature, dissolved nutrients, ions, organic matters, protozoa, etc. Ranges of fecal coliform population of 106.67 to $420.00 \mathrm{CFU} 100^{-1} \mathrm{ml}$ (Table-2) at the dilution level of $10^{1}$ was also found in close association with Sharma and Rajput (1996) and Sharma and Bhardwaj (2000). In the present finding, high population of fecal coliform during rainy seasons and low population during winter season (Table-2) were in consistent with the observation of Geldreich (1991), Joshi and Rajput (1992) and Islam et al. (1993). According to Thomas and Levin (1978) and Watnabe et al. (1981), fecal streptococci are mainly originated from the animal excreta because they are the normal habitat in the gastrointestinal tracts of warm blooded animals.

It is difficult to monitor the actual contamination sources in mixed cover watersheds since total coliform enumeration is general in nature and several streptococci are ubiquitous in soil and aquatic environment (Kebbey et al., 1978; Faust, 1982). The best data application for separating humans sources of contamination from other warm

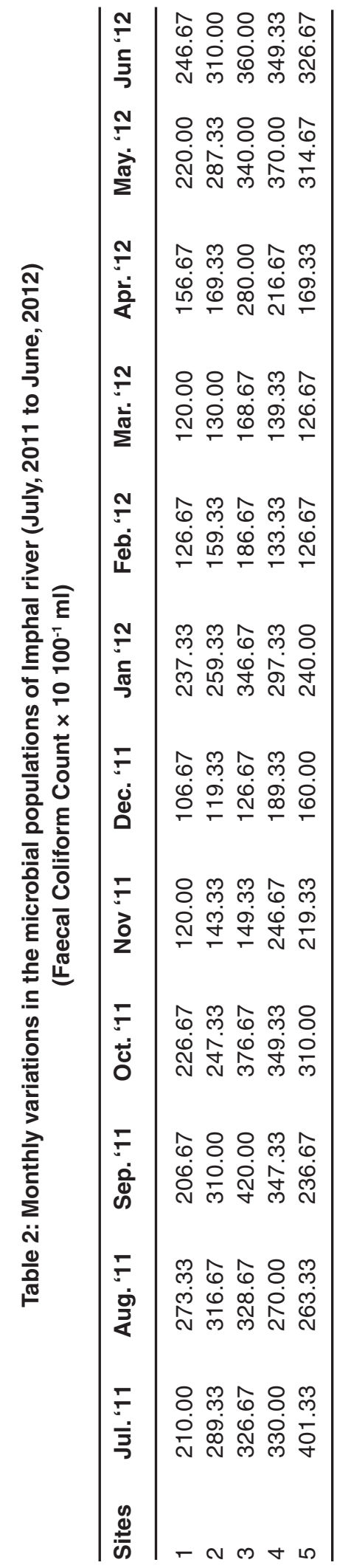


blooded sources of contamination may be fecal coliform (FC): fecal streptococci (FS) ratio over time (Cooper and Knight, 1989). According to Geldreich (1976), Baxter-potter and Gilliland (1988), the ratio less than 1.0 indicated warm blooded animal pollution while ratio of 4.0 or more suggested domestic waste pollution. During the study period 66 percent of all the samples had a ratio greater than 4.0 while 50 percent had a ratio greater and 1.0 (Table-4). These ratio indicated that domestic waste pollution is common than the warm blooded animal pollution.

According to Cooper and Knight (1989) coliform count could not be linked statistically with physical parameters because variability of indicator bacteria masked relationships as shown by large site-to-site fluctuations in bacterial count. He also stated that coliform counts did not vary with incremental changes in stage $( \pm 0.1 \mathrm{~m})$ or with instream suspended sediment concentrations, which were excellent indicators of rainfall and runoff. In the present study, it was observed that during summer there were insignificant variations of coliform count, which might be due to low rainfall activity. This is in agreement with the findings of Robbins et al., (1972) that all coliform indicator groups were significantly higher in rainy season than the preceding summer or following winter. Robbins et al., (1972) also indicated that coliform concentrations were overshadowed by large-scale hydrologic events but most water quality parameters did not produce statistically significant equation for predicting bacterial pollution.

In the rainy season coliform bacterial population were found to be significantly fluctuating. This might be due to input of allochthonous material by influx of rainwater and soil, which impart significant variation of bacterial population. In the present study, analysis of variance of the critical value of ' $F$ ' at $5 \%$ level during rainy season revealed significant effect on the density of total coliform $(P<0.05)$ and fecal coliform $(P<0.05)$, while fecal streptococci revealed insignificant effect $(P<0.05)$. However, significant differences were observed in summer and winter at the level of $p<0.05$ to $P<0.01$ for all the bacteria except faecal coliform which shown insignificant differences during winter $(P>0.05)$. Their significance differences indicated

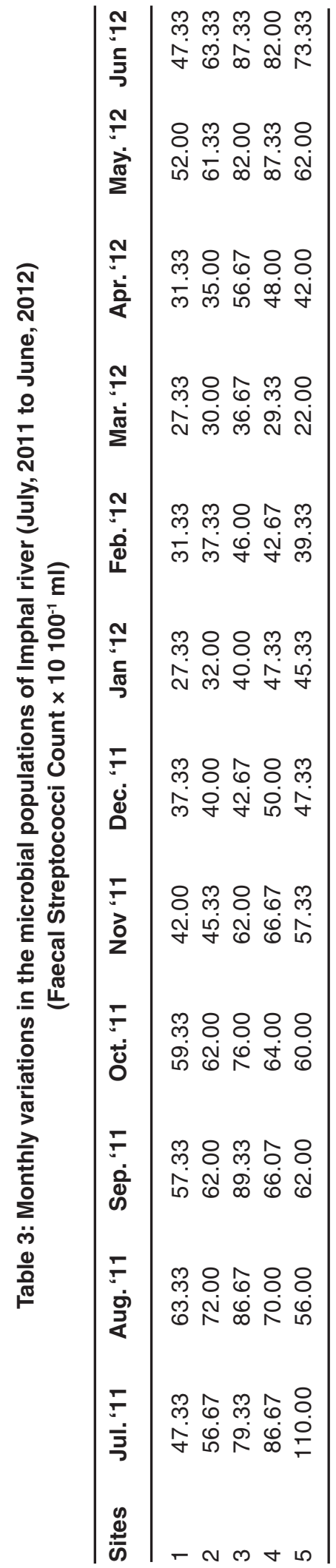


continuous contamination of domestic and animal wastes along with run-off during rainy season. This is also in agreement with the finding of Sharma and Bharadwaj (2000). They also stated that correlation between total coliform and rainfall was found to be positively significant and it appears that human inhabitation and other activities based on land usage around the water body were responsible for the input of indicator organisms. Cooper and Knight (1989) also showed marked significant seasonal and monthly differences $(P<0.05)$ of fecal coliform and fecal streptococci at two different locations of Agarian hill land streams due to rainfall pattern over the area. Hill and Webb (1958) also reported that the variability of bacterial count at different sites was found correlated with the sources of pollution. They found that bacteria formed an important link between primary producers and consumers, so it would appear that pollution affects the aquatic food chain. Flint (1989) reported that survival of $E$. coli in filtered water was due to the presence of some organic materials. It is therefore, possible that specific bacterium survives with specific form of organic matter and this impart in the variability of species composition. So, the results in the present study were closely associated with the above observations.

Thus, from the above results it is clear that the bacterial population had varied densities in different seasons which was influenced by the different environmental factors and their persistence at different densities in the river water throughout the study period offer an excellent opportunity to characterize the microbial quality of the water system and it is suggested that the river water is not suitable even for domestic purposes and need to be treated before use from hygienic point of view.

\section{Table 4: Fecal Coliform : Fecal Streptococci ratio of Imphal River from July, 2011 to June, 2012}

\begin{tabular}{lccccc}
\hline Months & \multicolumn{5}{c}{ Sites } \\
\cline { 2 - 6 } & $\mathbf{1}$ & $\mathbf{2}$ & $\mathbf{3}$ & $\mathbf{4}$ & $\mathbf{5}$ \\
\hline July '11 & 4.43 & 5.11 & 4.12 & 3.81 & 3.65 \\
Aug. '11 & 4.31 & 4.40 & 3.79 & 3.86 & 4.70 \\
Sep. '11 & 3.60 & 5.00 & 4.70 & 5.25 & 3.81 \\
Oct.'11 & 3.82 & 3.99 & 4.96 & 5.46 & 5.16 \\
Nov. '11 & 2.86 & 3.16 & 2.41 & 3.70 & 3.83 \\
Dec. '11 & 2.86 & 4.98 & 2.97 & 3.79 & 3.38 \\
Jan. '12 & 8.67 & 8.10 & 8.67 & 6.28 & 5.29 \\
Feb. '12 & 4.04 & 4.27 & 4.06 & 3.12 & 3.22 \\
Mar. '12 & 4.44 & 4.33 & 4.60 & 4.75 & 5.75 \\
Apr. '12 & 5.00 & 4.84 & 4.94 & 4.51 & 4.03 \\
May '12 & 4.23 & 4.68 & 4.15 & 4.24 & 3.84 \\
Jun. '12 & 5.21 & 4.89 & 4.12 & 4.26 & 4.45 \\
\hline
\end{tabular}

\section{REFERENCES}

1. Akpata, T.V.I., Oyenekan, J.A. and Nwanko, D.I., Impact of organic pollution on the bacterial, plankton and benthic population of Lagos lagoon, Nigeria. Intl. J. Eco. and Env. Sci. 19: 73 - 82 (1993).

2. APHA. Standard Methods for the Examination of Water and Waste Water
Analysis, (17th Edn.), Washington D.C (1989).

3. Bagde, U.S. and Verma, A.K., Distribution and periodicity of total, fecal coliform bacteria in aquatic ecosystem. Intl. J. Environ. Studies 19: 215-220 (1982).

4. Baxter-Potter, W.R. and Gilliland, M.W. 
Bacterial population in runoff from agricultural lands. J. Envron. Qual. 17: 2734 (1988).

5. Buchanan, R.E. and Gibbon, N.E., Bergey's Mannual of Determinative Bacteriology (9th Edn.), The Williams and Wikkins Co. Baltimore, M.D (1984).

6. Burton, G.W., Gunnison, Jr. D. and Lanza, G.D. Survival of pathogenic bacteria in various freshwater sediments. Appl. Environ. Microbiol. 53: 633-638 (1987).

7. Cooper, C.M. and Knight, S.S., Bacterial contamination in two Agarian Hill Land stream in Northern Mississipi, U.S.A. Intl. J. Ecol. Environ. Sci. 15: 85-96 (1989).

8. Crane, S.R., Moore, J.A., Grismer, M.E. and Miller, J.R., Bacterial pollution from agricultural sources: A review. Trans. ASAE 26: 858-872 (1983).

9. Das, S.M. and Pande, J., Pollution, Fish mortality and Environmental parameters in lake Nainital. J. Bombay Nat. Hist. Soc. 79: 100-109 (1986).

10. Fatma, F., El-Toumi, Boju, S., Adrawi, M. and Nair, G.A., An Ecological Approach to Ain Zayanah Lagoon, Banghazi, Libya, Eco. Env. \& Cons. 3(3-4): 117-120 (1997).

11. Faust, M.A., Aotakey, A.E. and Hargadon, M.T. Effect of physical parameters on the in situ survival of Escherichia coli MS-6 in estuarine environment. Appl. Microbiol., 30: 800-806 (1975).

12. Faust, M.A, Relationship between land-use practices and faecal bacteria in soil. $J$. Environ. Qual. 11: 141-146 (1982).

13. Flint, K.P., The long-term survival of Escherichia coli in river water. J. Appl. Bacteriology 63: 261-270 (1989).

14. Geldreich, E.E., Fecal coliform and fecal streptococci density relationships in waste discharges and receiving waters. CRC. Crit. Rev. Environ. Control 6: 349 (1976).

15. Geldreich, E.E., Microbial water quality concern for water supply use. Brock Springer Series in Contemporary Biosciences. Varlog, New York Inc (1991).

16. Hill, M.B. and Webb, J.E., The ecology of Lagos lagoon II. The topography and physical feature of Lagos harbour and Lagon lagoon. Philosophical Transaction of the
Royal Society of London 214(B): 319-333 (1958).

17. Islam, M.S., Hussain, M.K. and Khan, S.I., Growth and survival of Shigella in common Bangladeshi food under various conditions of time and temperature. Appl. \& Env. Microbiol. 59(2): 652-654 (1993).

18. Jama, B.B., Patel, G.N., Roy, S.K. and De, V.K., Growth characteristics of heterotropic bacterial population of water and bottom sediments in the tanks under different trophic conditions. Hydrobiologia 75: 231-239 (1986).

19. Joshi, A and Rajput, S. Distribution of some human pathogenic bacteria in two freshwater lakes at Jabalpur. Ind. J. Env. Protection 12 (5): 321-323 (1992).

20. Kebbey, H., Hagedorn, C. and McCoy, F., Use of fecal streptococci as indicators of pollution in soil. Appl. Environ. 35(4): 711-717 (1978).

21. Khalil, M.T., Impact of pollution on productivity and fisheries of lake Mariut, Egypt. Intl. J. of Ecol. and Envn. Sci. 26: 8997 (2000).

22. Khulbe, R.D., Sati, M.C. and Dhyani, A.P. Water pollution in Nainital lake; A survey. IN: perspectives in aquatic biology (Khulbe, R.D. Ed.), Papyrusi Publishing House, New Delhi (1989).

23. Knox, G.A., Estuarine Ecosystem: A system Approach. Vol. X. CRC Press Inc. Boca Roton, Florida (1986).

24. McKinney, R.E., Microbiology for Sanitary Engineers. McGrow-Hill, New York (1962).

25. McSwain, M.R. and Swank, W.J., Fluctuation in naturally occuring population of bacteria in oligotrophic water of Waster North Carolina. USDA Forest Service Res. Pap. SL: 158 (1997).

26. Nwachukwu, S.U., Akpata, T.V.I. and Essien, M.E., Microbiological assessment of industrial and domestic sewage at Agbara Industrial Estate (AIE) in Ogon state (Nigeria). Intl. J. Ecol. Environ. Sci. 15: 109-11 (1989).

27. Parker, R.E., Introductory Statistics for Biology. Edward Arnold (publisher) Ltd. 25Hill Street, London (1973).

28. P.J. Parmar, Orient J. Chem., 28(2): 927-931 (2012).

29. Rajender, K.S. and Khulbe, R.D., A survey of 
impact and evaluation of water pollution on reservoir fisheries in Kumaun Himalayas, India with special reference to microorganisms. Curr. Sci. 75 (12): 13031308 (1998).

30. Robbins, J.C., Howells, D.H. and Kriz, G.J. Stream pollution from animal production. J. Water Pollution Control. Fed. 44: 1536-1544 (1972).

31. Sah, J.P., Sah, S.K., Acharya, P., Pant, D. and Lance, V.A., Assessment of water pollution in the Narayani river, Nepal. Intl. J. Ecol. \& Environ. Sci. 26: 235-252 (2000).

32. Sharma, V.K. and Bharadwaj, R., Bacteriological investigation of the water of Kolayatzi village pond of Bikaner (Rajasthan). Uttar Pradesh J. Zool. 20(1): 79-82 (2000).

33. Sharma, A. and Rajput, S., Microbial quality and persistence of enteropathogenics in freshwater environment. Ecol. Env. \& Cons. 2: 29-36 (1996).

34. Shidhu, R.K. and Khulbe, R.D., A survey of impact and evaluation of water pollution on reservoir fishereis in Kumaun Himalayas,
India, with special reference to microrganisms. Current Science 75(12): 1303-1308 (1998).

35. M.R. Ansari, J. Ghomi and M. Riazian, Orient J. Chem., 27(4): 1523-1530 (2011).

36. Thomas, C.D. and Levin, M.A., Quantitative analysis of group D-streptococci. Abs. Annual Meeting. American Soc. Microbiology. p. 210 (1978).

37. Trivedy, R.K. , Goel, P.K. and Trisal, C.L., Practical Methods in Ecology and Environmental Science. Environmental publication, Karad, 340 (1987).

38. Tunnicliff, B. and Brinkler, S.K., Recreational water quality analysis of the Colorado River Carrider in Grand Canyon, USA. Appl. Environ. Microbiol. 48: 909-917 (1984).

39. Watanabe, T., Shimchashi, H., Kawai, Y. and Mutal, M., Studies on streptococci. I. Distribution of fecal streptococci in man. Microbiol. Immunol. 25: 275 (1981)

40. Weibel, S.R., Dixon, F.R., Weider, R.B. and McCabe, L.J., Water borne disease outbreak (1946-1960). J. Amm. Waterworks Assoc. 56(2): 947-958 (1964). 